\title{
Serum intact parathyroid hormone levels in cats with chronic kidney disease ${ }^{1}$
}

\author{
Luciano H. Giovaninni2*, Marcia M. Kogika², Marcio D. Lustoza², Archivaldo Reche \\ Junior $^{2}$, Vera A.B.F. Wirthl ${ }^{2}$, Denise M.N. Simões ${ }^{2}$ and Bruna M. Coelho ${ }^{2}$
}

\begin{abstract}
Giovaninni L.H., Kogika M.M., Lustoza M.D., Reche Jr A., Wirthl V.A.B.F., Simões D.M.N. \& Coelho B.M. 2013. Serum intact parathyroid hormone levels in cats with chronic kidney disease. Pesquisa Veterinária Brasileira 33(2):229-235. Departamento de Clínica Médica, Faculdade de Medicina Veterinária e Zootecnia, Universidade de São Paulo, Av. Prof. Dr. Orlando Marques de Paiva 87, São Paulo, SP 05508-270, Brazil. E-mail: lucianohq@usp.br

Chronic kidney disease (CKD) is frequently observed in cats and it is characterized as a multisystemic illness, caused by several underlying metabolic changes, and secondary renal hyperparathyroidism (SRHPT) is relatively common; usually it is associated with the progression of renal disease and poor prognosis. This study aimed at determining the frequency of SRHPT, and discussing possible mechanisms that could contribute to the development of SRHPT in cats at different stages of CKD through the evaluation of calcium and phosphorus metabolism, as well as acid-base status. Forty owned cats with CKD were included and divided into three groups, according to the stages of the disease, classified according to the International Renal Interest Society (IRIS) as Stage II $(\mathrm{n}=12)$, Stage III $(n=22)$ and Stage IV $(n=6)$. Control group was composed of 21 clinically healthy cats. Increased serum intact parathyroid hormone (iPTH) concentrations were observed in most CKD cats in all stages, and mainly in Stage IV, which hyperphosphatemia and ionized hypocalcemia were detected and associated to the cause for the development of SRHPT. In Stages II and III, however, ionized hypercalcemia was noticed suggesting that the development of SRHPT might be associated with other factors, and metabolic acidosis could be involved to the increase of serum ionized calcium. Therefore, causes for the development of SRHPT seem to be multifactorial and they must be further investigated, mainly in the early stages of CKD in cats, as hyperphosphatemia and ionized hypocalcemia could not be the only factors involved.
\end{abstract}

INDEX TERMS: Renal disease in cats, ionized calcium, hyperphosphatemia, secondary renal hyperparathyroidism, metabolic acidosis.

RESUMO.- [Avaliação das concentrações séricas de paratormônio intacto em gatos com doença renal crônica.] A doença renal crônica (DRC) em gatos é frequentemente observada e caracteriza-se como alteração multissistêmica, causada por alterações metabólicas, e o hiperparatireoidismo secundário renal (HPTSR) seria o mais comum e usualmente está associada com progressão da doença renal e mau prognóstico. Esse estudo teve como objetivo determinar a frequência do HPTSR, e discutir os possíveis

\footnotetext{
${ }^{1}$ Received on August 8, 2012.

Accepted for publication on November 22, 2012.

${ }^{2}$ Departamento de Clínica Médica, Faculdade de Medicina Veterinária e Zootecnia (FMVZ), Universidade de São Paulo (USP), Av. Prof. Dr. Orlando Marques de Paiva 87, São Paulo, SP 05508-270, Brazil. *Corresponding author: lucianohq@usp.br
}

mecanismos que podem contribuir para o desenvolvimento de SRHPT em gatos em diferentes estágios de DRC, pela avaliação do metabolismo do cálcio e fósforo, bem como do equilíbrio ácido-base. Quarenta gatos com DRC foram divididos em três subgrupos, de acordo com a classificação proposta pela International Renal Interest Society (IRIS), Estágio II $(\mathrm{n}=12)$, Estágio III $(\mathrm{n}=22)$ e Estágio IV $(\mathrm{n}=6)$. 0 grupo-controle foi composto por 21 gatos clinicamente saudáveis. 0 aumento das concentrações séricas de paratormônio intacto (PTHi) foi observado na maioria dos casos, mas principalmente no Estágio IV, no qual a hiperfosfatemia e a hipocalcemia ionizada parecem estar associadas ao desenvolvimento do HPTSR. No entanto, nos Estágios II e III, observou-se hipercalcemia ionizada, sugerindo que, nestes estágios, o desenvolvimento do HPTSR possa estar 
associado a outros fatores, e a acidose metabólica pode estar envolvida com o desenvolvimento de hipercalcemia ionizada. Assim, outros fatores, além da hiperfosfatemia e da hipocalcemia ionizada, possam estar envolvidos com o desenvolvimento do HPTSR, principalmente nos estágios iniciais da DRC. Futuros estudos são necessários para uma melhor compreensão da fisiopatologia do HPTSR em gatos.

TERMOS DE INDEXAÇÃO: Doença renal em gatos, cálcio iônico, hiperfosfatemia, hiperparatireoidismo secundário renal, acidose metabólica.

\section{INTRODUCTION}

Chronic kidney disease (CKD) is often diagnosed in cats (DiBartola et al. 1987, Lulich et al. 1992, Polzin et al. 1997, Elliott \& Barber 1998) and it is characterized by the presence of irreversible renal lesions, resulting in progressive impairment of renal function (Polzin \& Osborne 1995, Polzin et al. 1997), which leads to metabolic changes (Elliott \& Barber 1998, Polzin et al. 2009a). Cats with CKD may be asymptomatic, usually in the early stages, or may have a variety of clinical presentation during the progression of the disease (Elliott \& Barber 1998). Thus, identification of risk factors is important to provide earlier treatment and longer and better quality of life (Brown et al. 1997, Barber \& Elliott 1998). Secondary renal hyperparathyroidism (SRHPT) is an important metabolic change that causes organic disorders such as soft tissue mineralization (including kidneys), leading to nephron loss (Brown et al. 1997, Polzin et al. 1997, Barber \& Elliott 1998). Increased serum levels of intact parathyroid hormone (iPTH) are associated to poor prognosis and severity of feline CKD (Slatopolsky et al. 1980, Nagode et al. 1996, Barber \& Elliott 1998).

The pathophysiology of SRHPT is multifactorial and complex (Kidder \& Chew 2009). In the early stages (I and II) of CKD, according to the International Renal Interest Society (IRIS) classification, reduced renal excretion of phosphorus results in phosphorus retention, but phosphorus serum levels are usually within the normal range because of the compensatory mechanisms responsible for enhancing phosphaturia (Slatopolsky et al. 1980, Kidder \& Chew 2009, Wesseling-Perry K. 2010, Finch et al. 2011, Geddes et al. 2011). However, in the late stages (III and IV), those compensatory mechanisms could fail to prevent hyperphosphatemia, leading to inhibition of calcitriol synthesis that promotes reduction in serum ionized calcium and, in turn, stimulation in iPTH synthesis and secretion, and development of SRHPT (Krueger \& Osborne 1995, Goodman et al. 1996, Polzin et al. 2009b). According to the "trade off" hypothesis proposed by Slatopolsky et al. (1971) and studies in cats with CKD (Barber \& Elliott 1998, Pusoonthornthum et al. 2010), in advanced stages of the disease, the abnormalities observed in calcium and phosphorus homeostasis are enough to explain the pathophysiology of SRHPT. However, the pathophysiology of SRHPT in cats with CKD at early stages of the disease remains unclear.

Recent studies (Oliveira \& Moysés 2010, Wesseling-Perry 2010, Finch et al. 2011, Geddes et al. 2011, Williams et al. 2011) proposed a possible mechanism for the pathogenesis of SRHPT, involving fibroblast growth factor 23 (FGF23), a phosphotonin that is secreted by osteocytes and osteoblasts that plays an important physiological role in the regulation of phosphorous and vitamin D metabolism. FGF-23 acts by enhancing phosphaturia and inhibiting $1 \alpha$-hydroxylase in the presence of hyperphosphatemia, and in humans and cats, it has been observed that FGF-23 is already elevated in the early course of CKD, increasing even more as renal function declines, before any apparent abnormalities in serum calcium, phosphorus or iPTH are observed.

The role of phosphate in the etiopathogenesis of SRHPT has been confirmed in cats, dogs and humans (Krueger \& Osborne 1995, Goodman et al. 1996, Nagode et al. 1996, Plotnick 2007, Polzin et al. 2009b). In cats with CKD, the increase of one unit in serum phosphorus concentration has been associated with the elevation of $11.8 \%$ in the risk of death (Kidder \& Chew 2009), and serum phosphate above $7 \mathrm{mg} /$ dL could decrease serum iCa fraction and, in turn, increasing iPTH synthesis (Plotnick 2007). In humans with CKD, it is recommended to maintain serum phosphorus levels between 2.5 and $5.5 \mathrm{mg} / \mathrm{dL}$ in order to minimize the risk of mortality resulting from calcification of coronary arteries and renal tissue (Mendonça et al. 2002, Sesso \& Ferraz 2003, Rasouli \& Kiasari 2006). For cats with CKD, serum phosphorus levels should range from $2.7 \mathrm{mg} / \mathrm{dL}$ to $4.5 \mathrm{mg} / \mathrm{dL}$, and to $5 \mathrm{mg} / \mathrm{dL}$, or to $6 \mathrm{mg} / \mathrm{dL}$ in Stages II, III and IV, respectively (Elliott \& Watson 2009, Polzin et al. 2009a). Thus, hyperphosphatemia is regarded as one of the main factors responsible for the development of SRHPT, because it also may, per se, increase PTH RNA messenger synthesis (Ramasamy 2006).

Parathyroid hormone promotes bone calcium reabsorption and demineralization (Ramasamy 2006). In humans with CKD in the early stage, serum iPTH levels twice higher than the reference value is associated with bone lesions and early cardiovascular disease (Mendonça et al. 2002, Gomes et al. 2005, Rasouli \& Kiasari 2006). In dogs with SRHPT, other metabolic changes can also be seen, i.e. erythropoiesis inhibition, increased erythrocyte osmotic fragility (Murphy 1989) and decreased appetite (Weller 1985). Therefore, SRHPT contributes to CKD progression, leading to several changes, besides increasing morbidity and mortality rates (Slatopolsky et al. 1980, Barber \& Elliott 1998, Mendonça et al. 2002, Barber 2004, Notomi et al. 2006, Rasouli \& Kiasari 2006).

The aim of this study was to determine the frequency of SRHPT in cats at different stages of CKD by means of evaluation of calcium and phosphorus metabolism, as well as acid-base status, and to discuss possible mechanisms involved in the development of SRHPT.

\section{MATERIALS AND METHODS}

\section{Animals}

This study was approved by the Animal Care and Use Committee of the School of Veterinary Medicine and Animal Science of University of São Paulo (Protocol \#1353/2008).

Forty client-owned cats with CKD were considered for inclusion in the study [median age of 10.6 year-old, ranging from 1.7 
to 21 year-old; from different breeds (short-haired domestic and also mongrel or crossbreed); female or male; spayed or neutered]. They were referred to Veterinary Teaching Hospital, School of Veterinary Medicine and Animal Science, University of São Paulo. Diagnosis of CKD was based on chronic or persistent renal azotemia (longer than 3 months), associated with clinical signs such as loss of appetite, emesis, weight loss, polyuria and polydipsia. Cats with CKD were classified into three stages according to the IRIS staging system, based on serum creatinine concentrations in patients in normovolemia (Elliott \& Watson 2009) as CKD in Stage II ( $\mathrm{n}=12$; creatinine within the range of 1.6 to $2.8 \mathrm{mg} / \mathrm{dL}$ ), CKD in Stage III ( $\mathrm{n}=22$; creatinine between 2.9 to $5.0 \mathrm{mg} / \mathrm{dL}$ ), and CKD in Stage IV ( $\mathrm{n}=6$; creatinine above $5.0 \mathrm{mg} / \mathrm{dL}$ ). Cats with concurrent diseases, or those treated with vitamin D or calcium supplementation, were excluded.

The control group was composed of 21 clinically healthy cats (median age of 4.3 year-old, ranging from 0.7 to 11.3 year-old) that they were selected from 61 cats of a wide range of ages and asymptomatic, according to clinical history and physical exam; however, among them, only 21 cats had normal values of CBC and serum biochemistry (creatinine, urea, sodium, potassium and albumin). Although the effort to compose an age-matched control group, most of the older cats had laboratorial abnormalities.

\section{Laboratory data}

Venous blood was collected anaerobically after 8 to $10 \mathrm{hrs}$ fasting at morning period. For iPTH measurements, blood was collected into vacuum serum tube and fractionated in a refrigera- ted centrifuge (Sorvall RT7). Serum samples were stored at $-80^{\circ} \mathrm{C}$ for further analyses. Intact PTH was determined by immunoradiometric assay (Diagnostic Systems Limited Inc.), according to a previously protocol validated for serum PTH measurements in cats (Barber et al. 1993, Bolliger et al. 2008, Pusoonthornthum et al. 2010). All samples were assayed in duplicates.

For biochemical analyses, standard autoanalyzer techniques (Automatic analyzer RA-100, Technicon - Bayer) were used for total calcium (Sarkar \& Chauhan 1967) and phosphorus (Berti 1987) measurements. Ionized calcium (iCa) was measured (Chew \& Meuten 1982) using ion-selective electrode method (AVL OMNI 4 - Roche). Venous blood samples were collected anaerobically in a lithium heparin syringe for determination of blood $\mathrm{pH}$, gases and bicarbonate levels (AVL OMNI 4 - Roche), and measurements were performed within 30 minutes after blood collection.

\section{Statistical analysis}

Kolmogorov-Smirnov test was performed in order to evaluate the normality of data distribution. Nonparametric statistical tests, such as (a) Mann-Whitney (to investigate differences between control group and CKD group), and (b) Kruskal-Wallis, followed by Dunn test (to investigate differences among control group and CKD subsets of Stages II, III and IV) were used. Only for blood pH data, Student $t$ test and ANOVA were performed.

Reference ranges of all variables were defined from control group and expressed as the $90 \%$ confidence interval bounded by 5 th and 95 th percentiles. Since data had normal distribution in these animals; these ranges were used to determine the fre-

Table 1. Serum intact parathyroid hormone (iPTH), phosphorus, ionized calcium (iCa) and total calcium levels, as well as acid-base status of cats with chronic kidney disease (CKD) and clinically normal cats (control group)

\begin{tabular}{|c|c|c|c|c|c|c|}
\hline \multirow[t]{2}{*}{ Variables } & \multicolumn{3}{|c|}{ Groups } & \multicolumn{3}{|c|}{ Subsets } \\
\hline & & Control & CKD & CKD Stage II & CKD Stage III & CKD Stage IV \\
\hline \multirow{5}{*}{ iPTH * } & & $(n=21)$ & $(n=40)$ & $(n=12)$ & $(n=22)$ & $(n=6)$ \\
\hline & Mean & 27.4 & 207.0 & 133.8 & 167.4 & 498.4 \\
\hline & Median & 23.44 & $86.62^{p=0.004}$ & 85.55 & 67.87 & $415.64^{p<0.001}$ \\
\hline & SEM & 3.58 & 40.86 & 51.69 & 42.43 & 164.48 \\
\hline & Range & $3.15-58.9$ & $5.0-1126.6$ & 5.0-667.5 & $5.0-723.6$ & $34.3-1126.6$ \\
\hline \multirow[t]{4}{*}{ Phosphorus * } & Mean & 4.4 & 6.5 & 5.0 & 5.6 & 12.7 \\
\hline & Median & 4.4 & $5.15^{p=0.0117}$ & 4.85 & 5.1 & $12.75^{p<0.001}$ \\
\hline & SEM & 0.19 & 0.56 & 0.29 & 0.51 & 1.61 \\
\hline & Range & $2.5-6.0$ & $2.5-17.3$ & $3.9-7.5$ & $2.5-12.0$ & 7.8-17.3 \\
\hline \multirow[t]{4}{*}{$\mathrm{iCa}^{*}$} & Mean & 5.2 & 5.3 & 5.7 & 5.3 & 4.6 \\
\hline & Median & 5.2 & 5.2 & 5.45 & 5.2 & 4.7 \\
\hline & SEM & 0.03 & 0.02 & 0.25 & 0.07 & 0.22 \\
\hline & Range & $5.1-5.6$ & $4.0-7.3$ & $4.8-7.3$ & $4.7-6.0$ & $4.0-5.3$ \\
\hline \multirow[t]{4}{*}{ Total calcium * } & Mean & 9.4 & 9.8 & 10.3 & 9.5 & 9.6 \\
\hline & Median & 9.5 & 9.65 & 9.9 & 9.55 & 9.9 \\
\hline & SEM & 0.15 & 0.21 & 0.54 & 0.22 & 0.36 \\
\hline & Range & 8.2-10.8 & 7.1-13.8 & 7.1-13.8 & $7.4-11.1$ & 7.9-10.4 \\
\hline \multirow[t]{4}{*}{$\mathrm{pH}^{* *}$} & Mean & 7.3 & 7.299 & 7.295 & 7.302 & 7.299 \\
\hline & Median & 7.305 & 7.315 & 7.303 & 7.325 & 7.322 \\
\hline & SEM & 0.06 & 0.067 & 0.049 & 0.078 & 0.058 \\
\hline & Range & $7.19-7.39$ & 7.01-7.44 & 7.21-7.37 & 7.01-7.44 & $7.20-7.35$ \\
\hline \multirow[t]{4}{*}{$\mathrm{HCO}_{3}^{-*}$} & Mean & 20.2 & 17.7 & 17.8 & 17.4 & 18.7 \\
\hline & Median & 19.8 & $17.9^{p=0.0042}$ & 16.7 & $18.25^{p=0.0025}$ & 19.2 \\
\hline & SEM & 0.09 & 0.55 & 0.98 & 0.78 & 1.47 \\
\hline & Range & $16.9-23.6$ & $6.7-22.8$ & $13.3-22.3$ & $6.7-22.8$ & $12.9-22.3$ \\
\hline
\end{tabular}

* Mann-Whitney and Kruskal-Wallis tests, ${ }^{* *}$ student $t$ test and analysis of variance (ANOVA), SEM = standard error mean. 
quency of laboratorial variables as increased or decreased values in all cats with CKD, as well as at different stages of the disease.

According to the normality of distribution of analyzed variables, Spearman or Pearson ranking tests were used and correlation coefficients calculated. Significance was defined as $p<0.05$.

\section{RESULTS}

Serum iPTH and phosphorus levels were significantly increased in the group with CKD. However, comparing the different stages of cats with CKD, significant difference was noticed only in Stage IV (Table 1). Increased serum iPTH was detected in $57.5 \%$ of the cats in the group with CKD (including Stages II, III and IV). With regard to different stages (II, III and IV) of CKD, increased serum concentrations of iPTH were detected in 58.3\%, 50\% and $83.3 \%$, respectively (Table 2). Hyperphosphatemia was observed in 35\% of all cats with CKD, and in $16.7 \%, 27.3 \%$ and $100 \%$ in Stages II, III and IV, respectively (Table 2).

Serum iCa was not significantly different between control group and CKD group, as well as among the stages of CKD (Table 1). Although no statistical difference was detected regarding iCa, in Stage IV, 66.7\% of CKD cats had ionized hypocalcemia, and $33.3 \%$ had ionized normocalcemia (Table 2). On the other hand, ionized hypercalcemia was detected in Stages II and III, corresponding to $50 \%$ and $18.2 \%$, and ionized hypocalcemia in $8.3 \%$ and $9.1 \%$ respectively (Table 2).

No significant differences were noticed regarding serum total calcium levels and blood pH (Table 1). Significant decreased serum bicarbonate $\left(\mathrm{HCO}_{3}{ }^{-}\right)$concentrations (metabolic acidosis) were detected in cats of Stage III, and observed metabolic acidosis frequencies were 50\%, 40.9\% and 33.3\% in Stages II, III and IV, respectively (Tables 1 and 2). In addition, metabolic acidosis was noticed in 5 out of 10 cats presenting ionized hypercalcemia in Stages II and III.

Spearman (for serum concentration of iPTH, phosphorus, total calcium and iCa) or Pearson (for serum bicarbonate and $\mathrm{iCa}$ ) ranking tests were used to determine the correlation coefficients. Positive correlation (moderate degree) was observed between serum iPTH and phosphorus $(r=0.45 ; p=0.0032$; Spearman) in the group with all stages of CKD cats. Three cats from Stage II (3 of 12) and six cats from Stage III (6 of 22) showed increased IPTH and concurrent normophosphatemia and ionized normocalcemia. Two CKD cats of Stage IV had simultaneously the highest levels of serum phosphorus $(17.3 \mathrm{mg} / \mathrm{dL}$ and $15.6 \mathrm{mg} / \mathrm{dL})$ and the lowest levels of ionized calcium $(4.0 \mathrm{mg} / \mathrm{dL}$ in both cats), as well as increased of iPTH in both animals. Negative correlation (moderate degree) was detected between serum iPTH and iCa in all cats with CKD $(r=-0.48 ; p=0.0019$; Spearman), as well as in CKD cats of Stage III ( $r=-0.6$; $p=0.003$; Pearson).

\section{DISCUSSION}

Increased serum iPTH concentrations, observed in 57.5\% of the cats with CKD, were similar to those reported in other studies in cats (Barber \& Elliott, 1998, Pusoonthornthum et al. 2010) and dogs (Lazaretti et al. 2006), however, those reports in cats had not measured iPTH at different stages of CKD, according to the IRIS classification. In a study conducted by Barber \& Elliott (1998) involving 80 cats with CKD, the animals were subjectively categorized according to the severity of clinical signs; SRHPT was detected in $47 \%$ of CKD cats that were categorized as asymptomatic (which CKD was only evidenced by laboratorial exams), and in $100 \%$ of CKD cats categorized as presenting more

Table 2. Frequency (\%) of normal, increased, and reduced levels of serum intact parathyroid hormone (iPTH), phosphorus, ionized calcium (iCa), total calcium, blood $\mathrm{pH}$ and bicarbonate $\left(\mathrm{HCO3}^{-}\right)$of cats with chronic kidney disease (CKD)

\begin{tabular}{|c|c|c|c|c|c|}
\hline \multirow{2}{*}{$\begin{array}{c}\text { Variables } \\
\text { (cut-off values) }\end{array}$} & & \multirow{2}{*}{$\begin{array}{c}\text { Group } \\
\text { CKD } \\
(n=40)\end{array}$} & \multicolumn{3}{|c|}{ Subsets } \\
\hline & & & CKD & CKD & CKD \\
\hline PTHi & Increased & $57.5^{*}$ & 58.3 & 50 & $83.3^{*}$ \\
\hline \multirow[t]{2}{*}{$(5.4-60.2 \mathrm{pg} / \mathrm{mL})$} & Normal & 42.5 & 41.7 & 50 & 16.7 \\
\hline & Reduced & 0 & 0 & 0 & 0 \\
\hline Phosphorus & Increased & $35^{*}$ & 16.7 & 27.3 & $100 *$ \\
\hline \multirow[t]{2}{*}{$(2.7-6.1 \mathrm{mg} / \mathrm{dL})$} & Normal & 62.5 & 83.3 & 68.2 & 0 \\
\hline & Reduced & 2.5 & 0 & 4.5 & 0 \\
\hline $\mathrm{iCa}$ & Increased & 25 & 50 & 18.2 & 0 \\
\hline \multirow[t]{2}{*}{$(4.9-5.5 \mathrm{mg} / \mathrm{dL})$} & Normal & 57.5 & 41.7 & 72.7 & 33.3 \\
\hline & Reduced & 17.5 & 8.3 & 9.1 & 66.7 \\
\hline Total calcium & Increased & 12.5 & 16.7 & 13.6 & 0 \\
\hline \multirow[t]{2}{*}{ (8.1-10.7 mg/dL) } & Normal & 80 & 75 & 81.9 & 83.3 \\
\hline & Reduced & 7.5 & 8.3 & 4.5 & 16.7 \\
\hline $\mathrm{pH}$ & Increased & 2.5 & 0 & 4.5 & 0 \\
\hline \multirow[t]{2}{*}{$(7.18-7.42)$} & Normal & 90 & 100 & 86.4 & 83.3 \\
\hline & Reduced & 7.5 & 0 & 9.1 & 16.7 \\
\hline $\mathrm{HCO}_{3}^{-}$ & Increased & 0 & 0 & 0 & 0 \\
\hline \multirow{2}{*}{$(16.8-23.6 \mathrm{mmol} / \mathrm{L})$} & Normal & 57.5 & 50 & 59.1 & 66.7 \\
\hline & Reduced & $42.5^{*}$ & 50 & $40.9 *$ & 33.3 \\
\hline
\end{tabular}

*variables that showed significant different results $(\mathrm{p}<0.05)$. 
severe clinical signs (end-stage renal failure). Similar findings were observed herein: cats with CKD in advanced stage of the disease (Stage IV) had also shown significant increase in serum iPTH levels (83.3\%). Pusoonthornthu et al. (2010) also showed that iPTH levels were significantly increased in cats with end-stage CKD, which contributed to the decrease in survival rate.

In the present study, hyperphosphatemia was detected in $35 \%$ of all cats with CKD, and it could be the trigger for the development of SRHPT, as previously proposed by Slatopolsky et al. (1971) in the "trade off"' hypothesis, that involves the abnormalities in calcium and phosphorus homeostasis to explain the pathophysiology of SRHPT. Hyperphosphatemia detected in $100 \%$ of CKD cats of Stage IV may also have directly influenced iPTH synthesis. Furthermore, hyperphosphatemia may cause ionized hypocalcemia, as a result of the increase in other fraction of serum calcium that is chelated (law of mass equation) to phosphorus (Barber \& Elliott 1998, Greco \& Stabenfeldt 1999). In CKD cats of Stage IV, the decrease in free fraction of serum calcium (iCa) was observed in $66.7 \%$, and although this change did not have significant difference between control group and CKD cats of Stage IV, it is known that ionized hypocalcemia is also an important component in the regulation of synthesis and secretion of iPTH (Galbraith \& Quarles 1996, Barber \& Elliott 1998, Greco \& Stabenfeldt 1999, Ramasamy 2006, Schenck et al. 2006). A review paper about calcium metabolism described that 2\% decrease in serum iCa levels could increase iPTH synthesis by $400 \%$ (Galbraith \& Quarles 1996).

In accordance with the hypothesis previously mentioned, two cats of Stage IV revealed the highest values of serum phosphorus $(17.3 \mathrm{mg} / \mathrm{dL}$ and $15.6 \mathrm{mg} / \mathrm{dL})$ and the lowest values of ionized calcium $(4.0 \mathrm{mg} / \mathrm{dL}$ in both cats), as well as an increased of serum iPTH and a relevant impairment of their clinical condition. These findings were similar to those reported by Elliot \& Barber (1998) that observed hyperphosphatemia, increased serum levels of iPTH as well as ionized hypocalcemia associated with poor clinical condition in cats categorized subjectively as end-stage of CKD. In addition, in an analogous study in dogs with CKD, hyperphosphatemia and increased iPTH were detected in $100 \%(n=8)$ of the animals in Stage IV, as well as ionized hypocalcemia was observed in $87.5 \%$ (Cortadellas et al. 2010). Thus, in this present study, hyperphosphatemia seemed to be the main contributing factor for the development of SRHPT in CKD cats of Stage IV.

Cats with CKD in Stages II and III had no significant difference observed in iPTH, phosphorus and iCa (Table 1). Even though these statistical difference were not detected, ionized hypercalcemia was noticed in Stage II and III, and these findings may be considered for discussion because different mechanisms, other than the "trade off" hypothesis proposed by Slatopolsky et al. (1971), may be involved in the development of SRHPT in CKD cats of Stages II and III, in which elevated serum concentrations of iPTH was observed in $58.3 \%$ and $50 \%$, respectively. Ionized hypercalcemia plays an important role in the development of metastatic calcification, including the kidneys (Barber \&
Elliott 1998). Serum levels of iCa may also be affected by acid-base disorders; thus, metabolic acidosis may increase serum iCa levels by decreasing calcium fraction bound to protein or albumin (Chew \& DiBartola 1986, Rosol \& Capen 1996). In the present study, decreased blood $\mathrm{HCO}_{3}^{-}$(metabolic acidosis) was noticed in $50 \%$ and $40.9 \%$ of the cats of Stages II and III, respectively; therefore, ionized hypercalcemia, observed in those cats, could have been partially attributed to metabolic acidosis, mainly in cats of Stage III, since $\mathrm{HCO}_{3}^{-}$was significantly decreased in this subset. In addition, metabolic acidosis may also enhance osteoclastic iPHT activity and bone calcium efflux to the bloodstream, as well as may reduce directly serum levels of calcitriol and, therefore, contribute to SRHPT progression (Gomes et al. 2005). In humans with CKD, even in the early stages of the disease, metabolic acidosis and SRHPT have been described in conjunction with bone abnormalities (Gomes et al. 2005).

In ten cats with CKD of Stages II and III that had ionized hypercalcemia, 50\% of them had metabolic acidosis, thus, other mechanisms, and not only acid-base imbalance, should be considered in the development of ionized hypercalcemia in these animals. Possible mechanisms involved could be related to (a) decreased renal excretion of calcium and iPTH, (b) increased bone reabsorption mediated by iPTH, (c) lack of parathyroid glands feedback response to serum calcium levels, (d) increased intestinal calcium absorption (Chew \& Meuten 1982, Krueger et al. 1996, Polzin et al 1997), and even (e) autonomous parathyroid secretion (Chew \& DiBartola 1986, Feldman 1995, Galbraith \& Quarles 1996, Barber \& Elliott 1998, Barber 2004, Ramasamy 2006).

In cats with CKD in Stage II, hyperphosphatemia was detected in only $16.7 \%$ and increased serum iPTH in $58.3 \%$ (Table 2). Similar frequency of those results was also reported in a study in cats during the early stages of CKD, in which hyperphosphatemia was detected in 20\% and increased iPTH in 47\% (Barber \& Elliott 1998). Therefore, these findings may suggest that other mechanisms, besides hyperphosphatemia, could lead to the increase in iPTH synthesis. Thus, further identification of these mechanisms involved could provide a better understanding of SRHPT pathophysiology, as well as improve the therapeutic management.

One of the limitations of the present study was the low number of animals included, as well as serum FGF-23 and calcitriol concentrations that could not be measured in order to investigate other factors that could be involved. Further studies should be directed toward the investigation of the role of FGF-23 in the development of SRHPT at different stages of CKD in cats, however, validation of the methodology must be performed previously. In a study in cats with CKD, serum calcitriol was significantly decreased in $80 \%$ and $20 \%$ of the cases subjectively characterized as "end-stage" and "uremic CKD", respectively (Barber \& Elliott 1998). Low serum levels of calcitriol can cause parathyroid gland cellular proliferation (Barber \& Elliott 1998, Ramasamy 2006, Schenck et al. 2006, Cortadellas et al. 2010). According to evidence-based medicine, administration of calcitriol has proven to be effective in the treatment of SRHPT 
in dogs with CKD, having scientific support for use in stages III or IV and even in the cases in which serum iPTH levels are within normal ranges (Polzin 2007, Polzin et al. 2009b, Roudebush et al. 2010). However, for cats with CKD in Stages III or IV, the use of calcitriol seems to have a weak scientific support, requiring further investigation (Hostutler et al. 2006, Polzin et al. 2009a).

In short, metabolic acidosis could have contributed to ionized hypercalcemia observed in CKD cats in Stages II and III, even though no statistical difference in iCa was detected among the Stages of CKD, and it did not seem to be directly affected by SRHPT. In cats with CKD in stage IV, hyperphosphatemia and ionized hypocalcemia may have had an important role to increase serum iPTH, however in Stages II and III, other factors, besides hyperphosphatemia and ionized hypocalcemia, seem to be involved. Further investigations are needed to provide better understanding of the pathophysiology of SRHPT, mainly in the early stages of CKD in cats.

Acknowledgements.- For the grant from the Research Support Foundation of São Paulo State - FAPESP (Fundação de Amparo a Pesquisa do Estado de São Paulo).

\section{REFERENCES}

Barber P.J., Elliott J. \& Torrance A.G. 1993. Measurament of feline intact parathyroid hormone: assay validation and sample handling studies. J. Small Anim. Pract. 4:614-620.

Barber P.J. \& Elliott J. 1998. Feline chronic renal failure: calcium homeostasis in 80 cases diagnosed between 1992 and 1995. J. Small Anim. Pract. 39:108-116.

Barber P.J. 2004. Disorders of the parathyroid glands. J. Fel. Med. Surg. 6:259-69.

Berti G., Fossati P., Eril G.V.M., Tarengghi G. \& Musetellir C. 1987. Enzimatic colorimetric assay of inorganic phosphate. Clin. Chem. 33:312.

Bolliger A.P., Graham P.A., Richard V., Rosol T.J., Nachreiner R.F. \& Refsal K.R. 2008. Detection of parathyroid hormone-related protein in cats with humoral hypercalcemia of malignancy. Vet. Clin. Pathol. 31:3-8.

Brown S.A., Crowell W.A., Brown C.A., Barsanti J.A. \& Finco D.R. 1997. Pathophysiology and management of progressive renal disease. Vet. Journal 154:93-109.

Chew D.J. \& Meuten D.J. 1982. Disorders of calcium and phosphorus metabolism. Vet. Clin. North Am. Small Anim. Pract. 12:411-438.

Chew D.J. \& DiBartola S.P. 1986. Manual of Small Animal Nephrology and Urology. $3^{\text {rd }}$ ed. Churchill Livingstone, New York, 526p.

Cortadellas O., Palacio M.J.F., Tavalera J. \& Bayo'n A. 2010. Calcium and phosphorus homeostasis in dogs with spontaneous chronic kidney disease at different stages of severity. J. Vet. Intern. Med. 24:73-79.

DiBartola S.P., Rutgers H.C., Zack P.M. \& Tarr M.J. 1987. Clinicopathologic findings associated with chronic renal disease in cats: 74 cases (19731984). J. Am. Vet. Med. Assoc. 190:1196-1202.

Elliott J. \& Barber P.J. 1998. Feline chronic renal failure: clinical findings in 80 cases diagnosed between 1992 and 1995. J. Small Anim. Pract. 39:78-85.

Elliott J. \& Watson A.D.J. 2009. Chronic kidney disease: staging and management, p.883-891. In: Bonagura J.D. \& Twedt D.C. (Eds), Kirk's Current Veterinary Therapy XIV. Saunders Elsevier, St Louis, Missouri.

Feldman E.C. 1995. Disorders of the parathyroid glands, p.1437-1461. In: Ettinger S.J. \& Feldman E.C. (Eds), Textbook of Veterinary Internal Medicine. Vol.3. $4^{\text {th }}$ ed. W.B. Saunders, Philadelphia.

Finch N.C., Geddes R.F., Syme H. \& Elliott J. 2011. FGF-23 - Mediator of renal secondary hyperparathyroidism or a marker of glomerular filtration rate (GRF) in cats? Proc. ACVIM Forum, Denver, USA. J. Vet. Intern. Med. 25:632-767.

Galbraith S.C. \& Quarles L.D. 1996. Tertiary hyperparathyroidism and refractory secondary hyperparathyroidism, p.193-198. In: Favus M.J. (Ed.), Primer on the Metabolic Bone Disease and Disorders of Mineral Metabolism. $3^{\text {rd }}$ ed. Lippincott-Raven, Philadelphia.

Geddes R.F., Finch N.C., Elliott J. \& Syme H.M. 2011. Fibroblast growth factor 23 (FGF-23) in feline chronic kidney disease. Proc. ACVIM Forum, Denver, USA. J. Vet. Intern. Med. 25:632-767.

Gomes C.P., Silva M.I.B., Duarte M.E.L., Dorigo D., Lemos C.C.S. \& Bregman R. 2005. Bone disease in patients with chronic kidney disease under conservative management. São Paulo Med. J. 123:83-87.

Goodman W.G., Coburn J.W., Slatopolsky E. \& Salusky I.B. 1996. Renal osteodistrophy in adults and children, p.341-360. In: Favus M.J. (Ed.), Primer on the Metabolic Bone Disease and Disorders of Mineral Metabolism. $3^{\text {rd }}$ ed. Lippincott-Raven, Philadelphia.

Greco D. \& Stabenfeldt G.H. 1999. Endocrinologia, p.345-359. In: Cunningham J.G. (Ed.), Tratado de Fisiologia Veterinária. $2^{\text {nd }}$ ed. Guanabara Koogan, Rio de Janeiro.

Hostutler R.A., DiBartola S.P., Chew D.J., Nagode L.A., Schenck P.A., Rajala-Schultz P.J. \& Drost W.T. 2006. Comparison of the effects of daily and intermittent-dose calcitriol on serum parathyroid hormone and ionized calcium concentrations in normal cats and cats with chronic renal failure. J. Vet. Intern. Med. 20:1307-1313.

Kidder A.C. \& Chew D. 2009. Treatment options for hyperphosphatemia in feline CKD: What's out there? J. Feline Med. Surg. 11:213-224.

Krueger J.M. \& Osborne C.A. 1995. Canine and feline hypercalcemic nephropathy, p.416-440. In: Osborne C.A. \& Finco D.R. (Eds), Canine and Feline Nephrology and Urology. Willians and Wilkins, Philadelphia.

Krueger J.M., Osborne C.A., Nachreiner R.F. \& Refsal K.R. 1996. Hypercalcemia and renal failure, etilogy, pathophysiology, diagnosis and treatment. Vet. Clin. North Am., Small Anim. Pract. 26:1417-1445.

Lazaretti P., Kogika M.M., Hagiwara M.K., Lustoza M.D. \& Mirandola R.M.S. 2006. Concentração sérica de paratormônio intacto em cães com insuficiência renal crônica. Arq. Bras. Med. Vet. Zootec. 58:489-494.

Lulich J.P., Osborne C.A., O’brien T.D. \& Polzin D.J. 1992. Feline renal failure: Questions, answers, questions. Compend. Contin. Educ. Vet. 14:127-152.

Mendonça D.U., Lobão R.R.S. \& Carvalho A.B. 2002. Secondary hyperparathyroidism: An updated view of pathogenic and clinical aspects. J. Bras. Nefrol. 24:48-55.

Murphy M.B.P., Pierce K.R., Lowry S.R. \& Fisher J.W. 1989. Role of parathyroid hormone in the anemia of chronic terminal renal dysfunction in dogs. Am. J. Vet. Res. 50:1898-1905.

Nagode L.A., Chew D.J. \& Podell M. 1996. Benefits of calcitriol therapy and serum phosphorus control in dogs and cats with chronic renal failure. Vet. Clin. North Am., Small Anim. Pract. 26:1293-1330.

Notomi M.K., Kogika M.M., Ikesaki J.Y.H., Monteiro P.R.G. \& Marquesi M.L. 2006. Retrospective study of chronic renal failure cases in dogs between 1999 a 2002. Braz. J. Vet. Res. Anim. Sci. 43(Suppl.):12-22.

Oliveira R.B. \& Moysés R.M.A. 2010. FGF-23: State of the art. J. Bras. Nefrol. 32(3):323-331.

Plotnick A. 2007. Feline chronic renal failure: long-term medical management. Compend. Contin. Educ. Vet. 29:342-351.

Polzin D.J. \& Osborne C.A. 1995. Pathophysiology of renal failure and uremia, p.335-367. In: Osborne C.A. \& Finco D.R. (Eds), Canine and Feline Nephrology and Urology. Willians and Wilkins, Philadelphia.

Polzin D.J., Osborne C.A., Bartges J.W., James K.M. \& Churchill J.A. 1997. Insuficiência renal crônica, p.2394-2431. In: Ettinger S.J. \& Feldman E.C. (Eds), Tratado de Medicina Interna Veterinária. Vol.4. 4⿳⺈ ed. Manole, São Paulo.

Polzin D.J. 2007. 11 Guidelines for conservatively treating chronic kidney disease. Vet. Med. 102:788-799.

Polzin D.J., Osborne C.A. \& Ross S. 2009a. Evidence-based management of chronic kidney disease, p.872-878. In: Bonagura J.D. \& Twedt D.C. (Eds), Kirk's Current Veterinary Therapy. XIV. Saunders Elsevier, St Louis, Missouri. 
Polzin D.J., Ross S. \& Osborne C.A. 2009b. Calcitriol, p.892-895. In: Bonagura J.D. \& Twedt D.C. (Eds), Kirk's Current Veterinary Therapy. XIV. Saunders Elsevier, St Louis, Missouri.

Pusoonthornthum R., Pusoonthornthu P. \& Krishnamra N. 2010. Calcium-phosphorus homeostasis and changes in parathyroid hormone secretion in cats with various stages of spontaneous chronic renal failure. Compend. Clin. Pathol. 19:287-293.

Ramasamy I. 2006. Recent advances in physiological calcium homeostasis. Clin. Chem. Lab. Med. 44:237-273.

Rasouli M. \& Kiasari AM. 2006. Serum calcium and phosphorus associate with the occurrence and severity of angiographically documented coronary heart disease, possibly through correlation with atherogenic (apo) lipoproteins. Clin. Chem. Lab. Med. 4:43-50.

Rosol T.J. \& Capen C.C. 1996. Pathophysiology of calcium, phosphorus, and magnesium metabolism in animals. Vet. Clin. North Am., Small Anim. Pract. 26:1155-1181.

Roudebush P., Polzin D.J., Adams L.G., Towell T.L. \& Forrester S.D. 2010. An evidence-based review of therapies for canine chronic kidney disease. J. Small Anim. Pract. 51:244-252.

Sarkar B.C. \& Chauhan U.P.S. 1967. A new method for determining micro quantities of calcium in biological material. Anal. Biochem. 20:155-165.
Schenck P.A., Chew D.J., Nagode L.A. \& Rosol T.J. 2006. Disorders of calcium: hypercalcemia and hypocalcemia, p.122-194. In: DiBartola S.P. (Ed.), Fluid, Electrolyte, and Acid-base Disorders in Small Animal Practice. $3^{\text {rd }}$ ed. W.B. Saunders, St Louis.

Sesso R. \& Ferraz M.B. 2003. Critical appraisal of sevelamer for the treatment of hyperphosphatemia in patients with chronic renal failure. Revta Assoc. Med. Bras. 49:103-108.

Slatopolsky E., Cagla S., Pennell J.P., Taggart D.D. \& Canterbury J.M. 1971. On the pathogenesis of hyperparathyroidism in chronic experimental renal insufficiency in the dog. J. Clin. Investig. 50:492-499.

Slatopolsky E., Martin K. \& Hruska K. 1980. Parathyroid hormone metabolism and its potential as a uremic toxin. Am. J. Phys. 239:1-12.

Weller R.J., Cullen J. \& Dagle G.E. 1985. Hyperparathyroid disorder in dog: primary, secondary and cancer-associated (pseudo). J. Small Anim. Pract. 26:329-341.

Wesseling-Perry K. 2010. FGF-23 in bone biology. Pediatr. Nephrol. 25: 603-608.

Williams T.L., Elliott J. \& Syme H.M. 2011. Fibroblast growth factor 23 (FGF-23) concentrarions after treatment oh hyperthyroidism (HTM) in cats with variable renal function. Proc. ACVIM Forum, Denver, USA. J. Vet. Intern. Med. 25:632-767. 